\title{
New calcareous dinoflagellates (Calciodinelloideae) from the Middle Coniacian to Upper Santonian chalks of Lägerdorf (northern Germany)
}

\author{
TANIA HILDEBRAND-HABEL ${ }^{1} \&$ HELMUT WILLEMS ${ }^{2}$ \\ ${ }^{1}$ Department of Geosciences, University of Oslo, P.O. Box 1047 Blindern, N-0316 Oslo, Norway. \\ ${ }^{2}$ Department of Geosciences, University of Bremen, P.O. Box 330440, D-28334 Bremen, Germany.
}

\begin{abstract}
Three new calcareous dinoflagellate species from the Middle Coniacian to Upper Santonian chalks of Lägerdorf (northern Germany) are formally described: Calcicarpinum macrogranulum n. sp., Pirumella fragilis n. sp. and Ruegenia quinqueangulata $\mathrm{n}$. sp. The species show differing vertical distribution patterns which might result from local sea-level changes: $P$. fragilis and $R$. quinqueangulata are restricted to the possibly transgressive upper Mid-Coniacian to Lower Santonian interval and C. macrogranulum occurs consistently only in the probably regressive lower Mid-Coniacian and Middle to Upper Santonian intervals. J. Micropalaeontol. 23(2): 181-190, November 2004.
\end{abstract}

\section{INTRODUCTION}

Dinoflagellates producing calcareous tests (calcareous dinoflagellates) are important members of the Mesozoic and Cenozoic marine phytoplankton community. Although information on the ecological preferences of calcareous dinoflagellates is still scarce, their application as palaeoceanographical and palaeoclimatological tools has increased significantly in recent years, especially for the Late Quaternary of the Atlantic Ocean (e.g. Höll et al., 1999; Esper et al., 2000; Vink et al., 2000, 2001, 2002; Vink, 2004). Their usefulness for the interpretation of depositional environments is less well established. However, several studies indicate that calcareous dinoflagellates can be applied successfully in the fields of facies development (e.g. Dias-Brito, 1985; Zügel, 1996) and sequence stratigraphy (Zügel, 1994; Reháková, 2000).

Assemblage changes were often interpreted to be controlled by sea-level fluctuations, particularly for the Jurassic and Cretaceous (e.g. Keupp \& Ilg, 1989; Keupp, 1992, 1995a, 2001; Zügel, 1994; Hildebrand-Habel \& Willems, 1997; Reháková, 2000). To further elucidate the influence of sea-level changes on the distribution of calcareous dinoflagellates, the systematic inventory of the assemblages from the standard section for the Upper Cretaceous white chalk of northern Germany (Lägerdorf-Kronsmoor-Hemmoor) was begun (Willems, 1985, 1988, 1990, 1994; Hildebrand-Habel \& Willems, 1997; several unpublished diploma theses in the Department of Geosciences of Bremen University, Germany). The present study adds taxonomic information on previously illustrated and briefly described (Hildebrand-Habel \& Willems, 1997), but invalidly published, calcareous dinoflagellate species from the Middle Coniacian to Upper Santonian interval of this standard section. Hildebrand-Habel \& Willems (1997) described the vertical assemblage successions of this interval and their possible relation to sea-level changes, but they failed to validly publish the provisional names. These authors referred the names to a submitted manuscript, thereby illegally using the names in anticipation of future acceptance. Since the announced formal description has not been published in the meantime, the present paper corrects this deficiency to validate these species.

\section{MATERIAL}

The sample material is from the 'Schinkel' quarry near Lägerdorf (northern Germany). The Lägerdorf section forms part of a $415 \mathrm{~m}$ thick continuous sequence of white chalk, ranging in age from Middle Coniacian to Lower Maastrichtian, which has been uplifted by the 'Krempe' salt ridge and which is exposed in three quarries at Lägerdorf and Kronsmoor, about $50 \mathrm{~km} \mathrm{NW}$ of Hamburg (Fig. 1b). Together with the Maastrichtian chalks of Hemmoor, about $40 \mathrm{~km} \mathrm{SW}$ of Lägerdorf and Kronsmoor, the succession forms a sedimentologically and palaeontologically well-studied standard section for the Upper Cretaceous white chalk of northern Germany (e.g. Schönfeld et al., 1996). By measuring and consecutively numbering all recognizable beds, such as flint beds $(\mathrm{F})$, pyrite-impregnated beds $(\mathrm{G})$, marl beds and seams (M, B), horizons of marly chalks (mB) and clay streak beds (TS), a detailed log has been established to provide a basis for lithostratigraphic correlation of the individual sections (e.g. Ernst, 1966; Ernst \& Schulz, 1974; Schulz, 1978; Schmid, 1982). The zero datum for the composite Lägerdorf-Kronsmoor-Hemmoor section is the Lower Campanian marl bed M1 (base of pilula Zone) of Lägerdorf.

The Middle Coniacian interval was known only from an exploration boring, until the southern corner of the 'Schinkel' quarry had been deepened in 1984-1985 (Schönfeld et al., 1996). The numbering of the Middle Coniacian samples examined in the present study (Fig. 1a) does not follow the usual lithostratigraphic scheme but was communicated by Dr J. Schönfeld (pers. comm., 1995).

The sediments consist of almost purely pelagic chalks, with carbonate contents predominantly exceeding $92 \%$ and only minor terrigenous input (Ehrmann, 1986). They are mostly fine grained; only $5-15 \%$ of the components show grain sizes larger than $63 \mu \mathrm{m}$ (Schulz et al., 1990). The fine fraction is primarily composed of coccoliths, with a quantitatively significant additional proportion of calcareous dinoflagellates and planktonic foraminifers (Schulz et al., 1990). The chalks were deposited in an epicontinental Boreal sea (Håkansson et al., 1974), probably at a water depth of 50-200 m, as indicated by the foraminiferal assemblages (Ernst, 1978). 


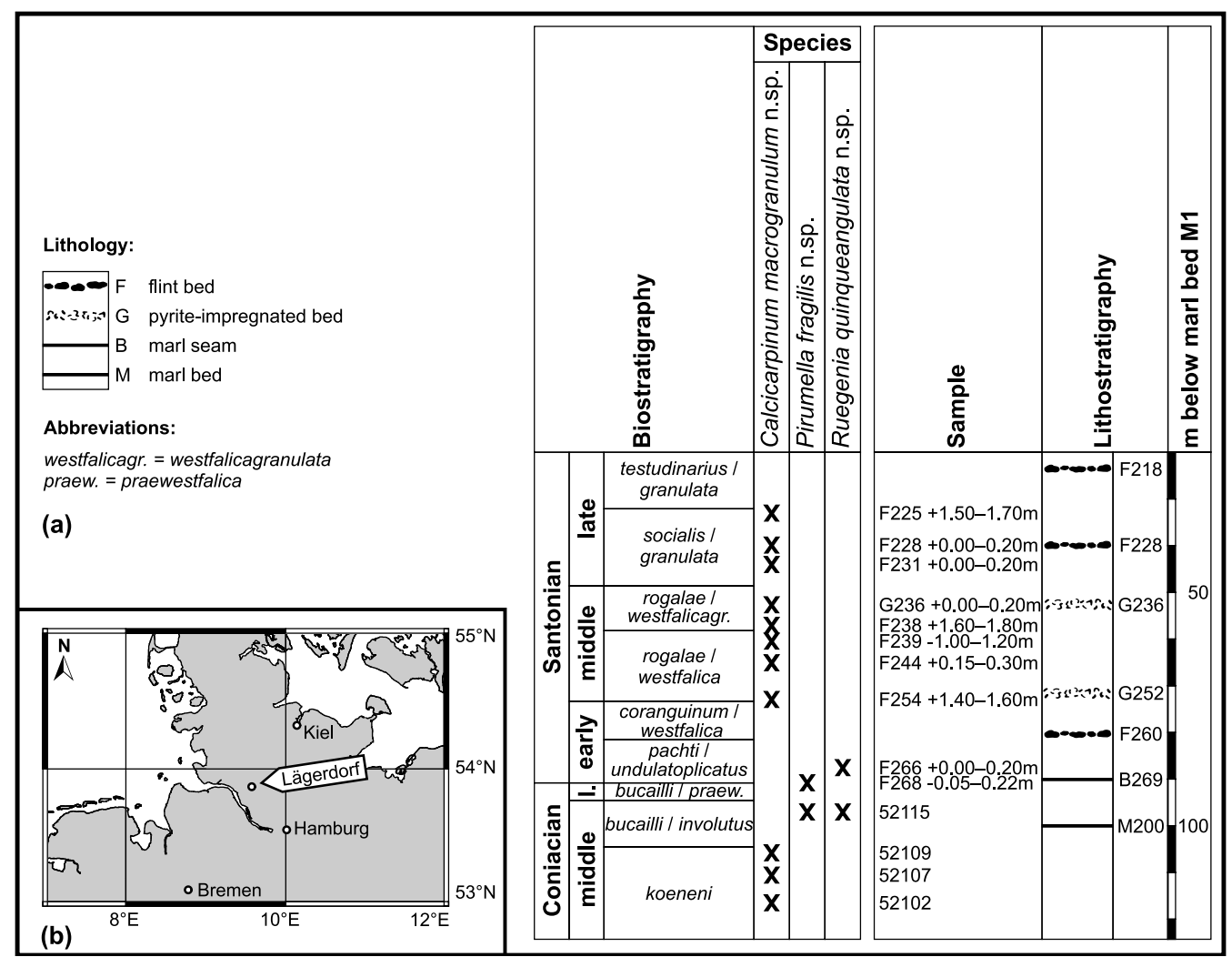

Fig. 1. (a) Occurrence of newly described species in the Middle Coniacian to Upper Santonian interval of Lägerdorf section. Biostratigraphy and lithostratigraphy of the chalks. The metre scale indicates the distance from the marl bed M1 (Lower Campanian, base of pilula Zone). (b) Geographical location of the studied Lägerdorf section in northern Germany.

A total of 24 chalk samples from the Middle Coniacian koeneni Zone to Upper Santonian socialis-granulata Zone of Lägerdorf were investigated for their content of calcareous dinoflagellates (Hildebrand-Habel \& Willems, 1997). The samples were studied at 3-4 m intervals. Fourteen analysed samples contained previously undescribed species (Fig. 1a).

\section{METHODS}

The material was processed by a combined Glauber's salt/deep freezing method (modified after Ernst, 1978). The samples were broken into fragments of about $1 \mathrm{~cm}^{3}$, which were soaked in saturated $\mathrm{Na}_{2} \mathrm{SO}_{4}$ solution and repeatedly frozen and thawed until a complete disintegration was achieved. They were then treated with ultrasound for 2-3 minutes to further separate and clean the particles. The suspension was wet-sieved through $125 \mu \mathrm{m}$ and $20 \mu \mathrm{m}$ screens and dried at $50^{\circ} \mathrm{C}$. A microspatula of the dried $20-125 \mu \mathrm{m}$ fraction was evenly scattered onto a picking tray and 100 calcareous dinoflagellate specimens were picked randomly with an eyelash at a magnification of $\times 80-160$, using a binocular microscope. The abundance of calcareous dinoflagellates in this fraction was simultaneously estimated. Subsequently, each sample was examined for rare or exceptional specimens. All selected specimens were mounted on aluminium stubs provided with double-sided adhesive tape, sputter-coated with gold and examined under a CamScan-44 scanning electron microscope (SEM). About one third of all specimens were subsequently broken with a scalpel, sputter-coated again and re-examined under the SEM to analyse the wall structure.

Several specimens of Calcicarpinum macrogranulum n. sp. were additionally prepared for crystallographic analysis in polarized light, following the procedure of Janofske (1996). By wetting its gelatinous surface, isolated specimens were attached to a strip of a developed negative film and afterwards sputtercoated with gold. After SEM examination, the film strip was embedded in Spurr's low viscosity resin. The hardened sample was cut into $3 \mu \mathrm{m}$ thin sections using a rotation microtome. To determine the wall type after Young et al. (1997), the thin sections were embedded in Canada balsam and examined under a Zeiss Axioplan light microscope.

\section{SYSTEMATIC DESCRIPTIONS}

Division Dinoflagellata (Bütschli, 1885) Fensome et al., 1993 Subdivision Dinokaryota Fensome et al., 1993 Class Dinophyceae Pascher, 1914

Subclass Peridiniphycidae Fensome et al., 1993 Order Peridiniales Haeckel, 1894 Suborder Peridiniineae Autonym Family Peridiniaceae Ehrenberg, 1831 Subfamily Calciodinelloideae Fensome et al., 1993

Genus Calcicarpinum Deflandre, 1948 emend. Keupp, 1984 emend. Versteegh, 1993 
Emended diagnosis. 'Obliquipithonelloid dinoflagellate cysts with subcircular to elongate endocoel and 3-5 faces. The single apical face contacts all other (2-4) faces of the cyst. Faces contact always at an angle of less than $90^{\circ}$ (Versteegh, 1993: $361)$.

Calcicarpinum macrogranulum $\mathrm{n}$. sp.

(Pl. 1, figs 7-15; Pl. 2, figs 1-3)

1997 Calcicarpinum macrogranulum Hildebrand-Habel \& Willems: 183, pl. 2, figs 8-10. Remark: name not validly published, used in anticipation of future acceptance (ICBN Article 34.1b).

1998 'Calcicarpinum macrogranulum' Hildebrand-Habel \& Willems; Williams et al.: 85.

Derivation of name. Macro (Gr.), meaning long, big; granulum (L.), meaning small grain. With reference to the wall built of both smaller crystals and extremely blocky units.

Diagnosis. Tetrahedral species with straight to convex edges; endocoel subcircular with a lining of seemingly tangentially arranged crystals; single-layered wall consists of crystals with obliquely orientated $c$-axes; blocky or thick-tabular units common; apical archaeopyle formed by the loss of plate 3' (Type A).

Holotype. Cyst 16/5, SEM micrographs 12/7/1-5 (P1. 1, figs 7-9).

Paratypes. Cyst 42/1, SEM micrographs 8/7/4-6, 9/1/1-4, 12/4/4 (Pl. 1, figs 10-12); cyst ZD2/13, SEM micrograph ZD2/6/2 (P1. 1, fig. 13); cyst 1/14, SEM micrographs 13/5/6, 13/6/1-5, X1/7/1-6, X5/1/2-3 (Pl. 1, figs 14-15; Pl. 2, fig. 1); cyst ZD2/0, SEM micrographs ZD2/1/1-6 (Pl. 2, figs 2-3).

Locality and horizon. Lägerdorf (northern Germany), 'Schinkel' quarry; Middle Santonian rogalae-westfalica Zone; sample F244 $+0.15-0.30 \mathrm{~m}$.

Other material studied. 44 cysts from the Middle Coniacian and Middle to Upper Santonian intervals of 'Schinkel' quarry, Lägerdorf.

Repository. Collection of the Division Historical Geology and Palaeontology, Department of Geosciences, Bremen University, Germany.

Description. Tetrahedral cysts with four planar faces. The epitract is reduced to an equilateral triangle and the hypotract forms a trigonal pyramid. Faces contact at straight (Pl. 2, fig. 1) to convex (P1. 1, fig. 10) edges. Edges often consist of coarse and coalesced crystals, resulting in a bulging protrusion ( $\mathrm{Pl}$. 1, fig. 13). The single-layered wall is built of irregularly shaped and arranged crystals ( $c$-axes randomly obliquely orientated; oblique wall type after Young et al., 1997). All specimens exhibit both smaller crystals and blocky or thick-tabular units, possibly attributable to diagenetic alteration (Pl. 1, fig. 15; Pl. 2, fig. 2). The subcircular endocoel may be eccentric and is lined by nearly tangentially arranged blocky-tabular crystals (P1. 2, fig. 3). Small circular archaeopyles (Type A) commonly occur; they are formed by the loss of the plate 3' (Pl. 1, figs 8-10).
Comparison. Three species of Calcicarpinum have a tetrahedral shape comparable to C. macrogranulum; however, they differ in their wall structures: Calcicarpinum primum Keupp, 1995b (Upper Albian of the Lower Saxony Basin, northern Germany Keupp, 1995b) has an extremely thin single-layered wall built of fibrous crystallites; Calcicarpinum tetraedricum Deflandre, 1948 (Eocene of Chaussy, France - Deflandre, 1948) also has a single-layered wall of minute crystallites; Calcicarpinum tetramurum Kienel, 1994 (Lower Paleocene of northern Jutland, Denmark - Kienel, 1994; Upper Maastrichtian to Upper Paleocene of DSDP Site 356, western South Atlantic - HildebrandHabel et al., 1999; Upper Maastrichtian to Upper Paleocene of DSDP Site 357, western South Atlantic - Hildebrand-Habel \& Willems, 2000; Lower and Upper Paleocene of ODP Hole 689B, Weddell Sea - Hildebrand-Habel \& Streng, 2003; Lower Paleocene of ODP Hole 747A, southern central Indian Ocean - Streng et al., 2004) has a double-layered wall of uniformly sized platy rhombohedra.

Dimensions. Holotype: length (apical-antapical) $34 \mu \mathrm{m}$; width (length of edges) $35 \mu \mathrm{m}$; archaeopyle $5 \mu \mathrm{m}$ ( $=14 \%$ of width). Other specimens: length of edges $28-46 \mu \mathrm{m}$ (mean $37 \mu \mathrm{m}$ ); archaeopyle 3-12 $\mu \mathrm{m}$ (mean $5 \mu \mathrm{m}$ ); wall thickness 3-9 $\mu \mathrm{m}$ in the centre of the tetrahedrons' faces and $8-16 \mu \mathrm{m}$ in the area of the edges.

Occurrence. Rare in the Middle Coniacian (koeneni Zone) and Middle Santonian (rogalae-westfalica Zone) to Upper Santonian (socialis-granulata Zone) intervals of Lägerdorf (northern Germany). Maximum abundance (5\% of the total calcareous dinoflagellate assemblage) in Middle Santonian sample F254 $+1.40-1.60 \mathrm{~m}$. C. macrogranulum was also found in the Upper Campanian chalks of Lägerdorf and Kronsmoor (K. Bison, pers. comm., 2000).

Genus Pirumella Bolli, 1980 sensu Lentin \& Williams, 1993

Remarks. According to Keupp (1981), the 'type species' of Pirumella - P. edithvincentae - is considered to be a taxonomic junior synonym of Pithonella (subsequently Obliquipithonella, now Pirumella) thayeri Bolli, 1974. Calcareous dinoflagellates with obliquely structured walls, not showing external tabulation, have been assigned to the genus Obliquipithonella Keupp (in Keupp \& Mutterlose, 1984) until recently. Following the arguments of Keupp (in Keupp \& Mutterlose, 1984), Lentin \& Williams (1985) proposed the new combination Obliquipithonella thayeri (Bolli, 1974) Lentin \& Williams, 1985. Thus, the genus Obliquipithonella is a junior synonym of Pirumella and Lentin \& Williams (1993) consequently transferred all species in Obliquipithonella to Pirumella. At present, all species with an obliquely structured wall and without external tabulation are accommodated in the genus Pirumella.

Pirumella fragilis n. sp. (Pl. 1, figs 1-6)

1997 Obliquipithonella fragilis Hildebrand-Habel \& Willems: 183, pl. 2, fig. 7. Remark: name not validly published, used in anticipation of future acceptance (ICBN Article 34.1b). 


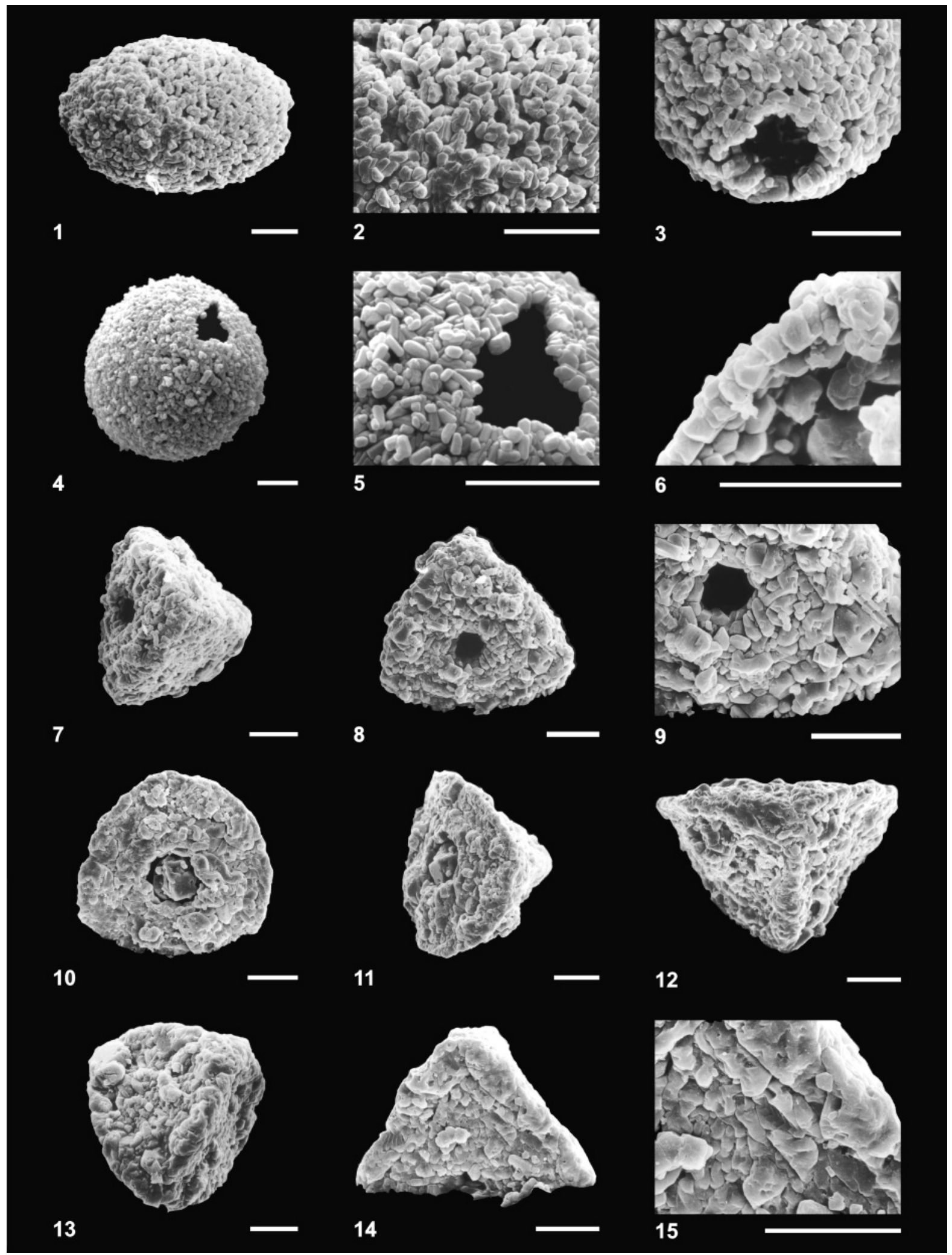


1998 'Obliquipithonella fragilis' Hildebrand-Habel \& Willems; Williams et al.: 426.

Derivation of name. Fragilis (L.), meaning fragile. With reference to the thin and fragile cyst wall.

Diagnosis. Spherical to elongated species of Pirumella with a thin single-layered wall; tiny crystals are angular to subrounded and randomly arranged; apical archaeopyle formed by the loss of plate 3' (Type A); a rim of crystals is arranged in parallel around the archaeopyle and slightly protrudes.

Holotype. Cyst 29/43, SEM micrographs 26/3/2-4 and 47/4/1 (P1. 1, figs 1-3).

Paratypes. Cyst 30/11, SEM micrographs 25/3/5-6, 25/4/1-2 (P1. 1, fig. 6); cyst Zü6/3, SEM micrographs 644/91, 645/91 (Pl. 1, figs 4-5).

Locality and horizon. Lägerdorf (northern Germany), 'Schinkel' quarry; Lower Santonian pachti-undulatoplicatus Zone; sample F268-0.05-0.22 m.

Other material studied. Six cysts from the Middle Coniacian interval of 'Schinkel' quarry, Lägerdorf.

Repository. Collection of the Division Historical Geology and Palaeontology, Department of Geosciences, Bremen University, Germany.

Description. The cysts of Pirumella fragilis are spherical to apically-antapically elongated, with a maximum length/width ratio of 1.8. The thin single-layered wall consists of angular to subrounded minute crystallites. These are randomly arranged within the wall, which argues for the oblique wall type after Young et al. (1997). However, the orientations of the crystallographic $c$-axes remain unproved. Due to diagenetic overgrowth, crystals exhibit a blockier habit on the proximal surface. The distal surface shows an irregular pattern of more or less loosely arranged crystallites (Pl. 1, fig. 2). All specimens exhibit openings, but attributed to the walls' tenuity, these commonly represent damage ( $\mathrm{Pl}$. 1, figs 4-5) or secondarily widened archaeopyles. The originally small circular archaeopyles (P1. 1, fig. 3) are only infrequently preserved. Principally, the archaeopyle is formed by the loss of the plate 3' (archaeopyle Type A). A succession of crystals is arranged in parallel around the archaeopyle and forms a distinct rim that often protrudes slightly.
Comparison. P. fragilis differs from the other species of Pirumella in the structure of the thin single-layered wall built by loosely arranged minute crystals. Another characteristic is the - often slightly protruding - rim of crystals framing the archaeopyle.

Dimensions. Holotype: length (apical-antapical) $48 \mu \mathrm{m}$; width $33 \mu \mathrm{m}$; length/width ratio 1.45 ; archaeopyle $8 \mu \mathrm{m} \quad(=24 \%$ of width); wall thickness $3.5 \mu \mathrm{m}$. Other specimens: length (apicalantapical) $42-62 \mu \mathrm{m}$; width $26-46 \mu \mathrm{m}$; length/width ratio 1.0 to 1.8 (mean 1.3 ); archaeopyle $5.5-8 \mu \mathrm{m}$; wall thickness $1.7-$ $3.8 \mu \mathrm{m}$.

Occurrence. Rare in the Middle Coniacian bucailli-involutus Zone and Lower Santonian pachti-undulatoplicatus Zone of Lägerdorf (northern Germany).

Genus Ruegenia Willems, 1992 emend. Kienel, 1994

Emended diagnosis. 'Spherical and paratabulated doublelayered calcareous dinoflagellate cysts. The crystallites of both wall-layers show differing orientations. Whereas they are strictly orthogonally arranged in the outer layer, they build an inner layer of irregularly oblique crystallites. The archaeopyle is located in the central apex and corresponds to the plate homologue 3" (translated from Kienel, 1994: 40).

\section{Ruegenia quinqueangulata $\mathrm{n}$. sp.}

$$
\text { (Pl. 2, figs 4-15) }
$$

1997 Ruegenia quinqueangulata Hildebrand-Habel \& Willems: 185-186, pl. 3, figs 12-15. Remark: name not validly published, used in anticipation of future acceptance (ICBN Article 34.1b).

1998 'Ruegenia quinqueangulata’ Hildebrand-Habel \& Willems; Williams et al.: 539.

Derivation of name. Quinque (L.), meaning five; angulatus (L.), meaning angular. With reference to the pentagonal antapical plate.

Diagnosis. Cyst with a reduced sutural tabulation; antapex flattened to a pentagonal antapical plate; wall double-layered; outer layer consists of orthogonally arranged stemmed crystals; inner layer consists of obliquely arranged equigranular rhombohedra; apical archaeopyle formed by the loss of plate 3' (Type A).

Explanation of Plate 1.

New calcareous dinoflagellates from the Middle Coniacian to Upper Santonian interval of Lägerdorf. All scale bars $10 \mu \mathrm{m}$. figs 1-6. Pirumella fragilis n. sp.: 1-3, holotype, cyst 29/43, sample F268 - 0.05-0.22 m, Lower Santonian pachti-undulatoplicatus Zone - 1, lateral view, 2, detail of distal surface, 3, apical view; 4-5, paratype, cyst Zü6/3, sample 52115, Middle Coniacian bucailli-involutus Zone - 4, lateral view, 5, detail of distal surface, damaged wall; 6, paratype, cyst 30/11, sample F268 -0.05-0.22 m, Lower Santonian pachti-undulatoplicatus Zone, cross-section of wall. figs 7-15. Calcicarpinum macrogranulum n. sp.: 7-9, holotype, cyst 16/5, sample F244 +0.15-0.30 m, Middle Santonian rogalae-westfalica Zone - 7, lateral-apical view, 8, apical view, 9, detail of distal surface; 10-12, paratype, cyst 42/1, sample 52107, Middle Coniacian koeneni Zone - 10, apical view, 11, lateral-apical view, 12, lateral view; 13, paratype, cyst ZD2/13, sample F238 +1.60-1.80 m, Middle Santonian rogalae-westfalicagranulata Zone, lateral view; 14-15, paratype, cyst 1/14, sample F225 +1.50-1.70 m, Upper Santonian socialis-granulata Zone - 14, lateral view, 15, detail of distal surface. 


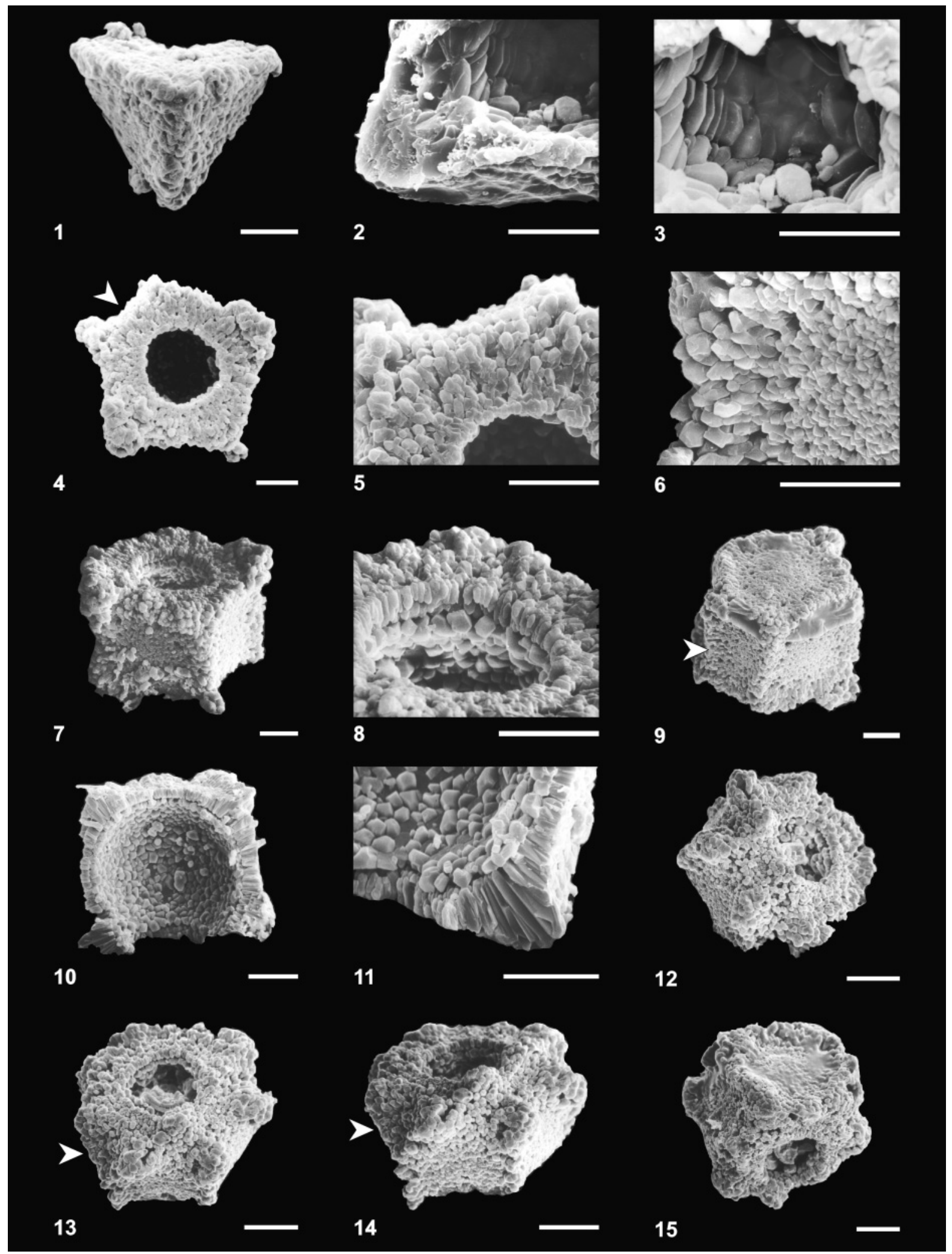


Holotype. Cyst 34/7, SEM micrographs 18/6/3-6, 18/7/1-4, 19/ 1/1-3, 19/2/1-6, 19/3/1-4, 28/5/6, 28/6/1-6, 28/7/1-6, 32/2/1-5, 32/3/1-5 (Pl. 2, figs 4-11).

Paratype. Cyst 27/14, SEM micrographs 30/6/2-6, 30/7/1-6, 31/1/1-4, 38/1/1-3, 47/1/4-5, 47/2/1-4, 53/7/1-4, 54/1/1 (P1. 2, figs 12-15).

Locality and horizon. Lägerdorf (northern Germany), 'Schinkel' quarry; Middle Coniacian bucailli-involutus Zone; sample 52115 (near G274-1.25 m).

Repository. Collection of the Division Historical Geology and Palaeontology, Department of Geosciences, Bremen University, Germany.

Description. Ruegenia quinqueangulata predominantly has a pentagonal symmetry (Pl. 2, figs 4, 9). The cingular series consist of five rectangular plates joining at distinct sutural ridges, thus forming a prism (Pl. 2, figs 7, 9). One plate is slightly narrower and might represent the sulcus ( $\mathrm{Pl}$. 2, figs 4, 9; arrows). The intersections of the ridges are commonly extended to nodes (Pl. 2 , figs 7,12$)$. The antapex is flattened to a pentagonal antapical plate (Pl. 2, fig. 9). The apical face of the holotype also has a pentagonal symmetry, whereas the paratype shows a heptagonal symmetry. These differences in symmetry result from the splitting of two antapical-apical ridges in the upper third of the paratype and the insertion of two triangular plates (Pl. 2, figs 13, 14; arrows). A circular archaeopyle (Type A) is formed by the loss of the plate 3 ' in the centre of the apex ( $\mathrm{Pl}$. 2, figs 4, 13). The wall is double-layered with an outer layer of orthogonally arranged stemmed crystals and an inner layer of obliquely arranged equigranular rhombohedra. The inner layer lines the spherical endocoel. Distal elongation of several rows of crystals in the outer layer constitutes the ridges (Pl. 2, fig. 11). The orientations of the $c$-axes - and, thus, the wall type after Young et al. (1997) - have not been verified by crystallographic methods.

Comparison. With its principally pentagonal geometry, Ruegenia quinqueangulata is comparable to Congruentia eocaenica Kohring (in Keupp et al., 1991). Different from C. eocaenica, however, is the insertion of triangular plates and the doublelayered wall in $R$. quinqueangulata. The structure of the doublelayered wall, with an outer layer of orthogonally arranged crystals and an inner layer of irregularly oblique arranged crystals, substantiates the affiliation of $R$. quinqueangulata with the genus Ruegenia Willems, 1992 emend. Kienel, 1994. The taxon differs from the other holotabulate species of Ruegenia, although $R$. crassa Kienel, 1994 has a similar wall structure, but differs in possessing a hexagonal geometry. $R$. areata Keupp et al., 1992 has a small pentagonal antapical plate, but an otherwise differing tabulation pattern. Additionally, $R$. areata has an inner layer of fibrous crystallites.

Dimensions. Holotype: length (apical-antapical) $32 \mu \mathrm{m}$; width $48 \mu \mathrm{m}$; length/width ratio 0.67 ; archaeopyle $18 \mu \mathrm{m}(=37.5 \%$ of width); thickness of outer wall-layer $2 \mu \mathrm{m}$ (centre of plates) to $9.5 \mu \mathrm{m}$ (ridges); thickness of inner wall-layer $1.2-1.8 \mu \mathrm{m}$. Paratype: length (apical-antapical) $25 \mu \mathrm{m}$; width $38 \mu \mathrm{m}$; length/width ratio 0.66 ; archaeopyle $14 \mu \mathrm{m}$ (=36.8\% of width); thickness of outer wall-layer $2.2-8.9 \mu \mathrm{m}$; thickness of inner wall-layer 1.4 $2.5 \mu \mathrm{m}$.

Occurrence. Rare in the Middle Coniacian bucailli-involutus Zone and Lower Santonian pachti-undulatoplicatus Zone of Lägerdorf (northern Germany).

\section{RESULTS AND DISCUSSION}

The examination of Middle Coniacian to Upper Santonian calcareous dinoflagellate assemblages from the chalks of Lägerdorf (Hildebrand-Habel \& Willems, 1997) revealed three new species. Although all three taxa are rare components of the associations, Calcicarpinum macrogranulum occurs more consistently in the Lägerdorf chalks than Pirumella fragilis and Ruegenia quinqueangulata. The species show vertical distributions that allow a stratigraphic subdivision of the section into three intervals: Middle Coniacian (koeneni Zone), upper MidConiacian to Lower Santonian, and Middle to Upper Santonian (Fig. 1a). Whereas C. macrogranulum occurs in the Middle Coniacian and Middle to Upper Santonian intervals, $P$. fragilis and $R$. quinqueangulata are present only in the late MidConiacian to Early Santonian times. There is no overlap in the occurrence of the latter two species with C. macrogranulum.

This vertical succession of species corresponds to the calcareous dinoflagellate assemblage changes as recognized for the Middle Coniacian to Upper Santonian interval by HildebrandHabel \& Willems (1997): the Middle Coniacian koeneni Zone is characterized by a relatively low absolute abundance, an increased diversity, generally lower proportions of the pithonelloid wall type and an increased proportion of the oblique and radial wall types; the late Mid-Coniacian to early Mid-Santonian interval shows a high absolute abundance, low diversity, low proportions of the oblique and radial wall types, high proportions of the pithonelloid wall type and a low Pithonella sphaericalPithonella ovalis ratio; the middle Mid-Santonian to Upper Santonian interval again has a low absolute abundance,

Explanation of Plate 2.

New calcareous dinoflagellates from the Middle Coniacian to Upper Santonian interval of Lägerdorf. All scale bars 10 $\mu \mathrm{m}$. figs 1-3. Calcicarpinum macrogranulum n. sp.: 1, paratype, cyst 1/14, sample F225 +1.50-1.70 m, Upper Santonian socialis-granulata Zone, lateral view; 2-3, paratype, cyst ZD2/0, sample F238 +1.60-1.80 m, Middle Santonian rogalae-westfalicagranulata Zone - 2, cross-section of wall, 3, subspherical endocoel and proximal surface. figs 4-15. Ruegenia quinqueangulata $\mathrm{n}$. sp.: 4-11, holotype, cyst 34/7, sample 52115, Middle Coniacian bucailli-involutus Zone - 4, apical view, arrow indicates narrower cingular plate (possibly sulcus?), 5-6, distal surface, 7, lateral-apical view, 8, detail of archaeopyle and wall structure, 9, lateral-antapical view, arrow indicates narrower cingular plate (possibly sulcus?), 10, broken cyst shows spherical endocoel, 11, cross-section of wall; 12-15, paratype, cyst 27/14, sample F266 +0.0-0.20 m, Lower Santonian pachti-undulatoplicatus Zone - 12, apical-lateral view, 13, apical-lateral view, arrow indicates one of the two inserted triangular plates, 14, lateral-apical view, arrow indicates one of the two inserted triangular plates, 15, lateral-apical view. 
an increased diversity, generally lower proportions of the pithonelloid wall type and an increased proportion of the oblique and radial wall types.

Generally, our understanding of the factors controlling the distribution of Late Cretaceous calcareous dinoflagellates is limited. However, Zügel (1994) documented that the distribution patterns in the Cenomanian/Turonian of western France and northern Germany are mainly influenced by sea-level changes, as a function of the palaeogeographical positions of the sections. Zügel (1994) recognized high abundances of the pithonelloid wall type, with Pithonella ovalis often dominating, to indicate transgressive systems tracts. Additionally, high abundances of the pithonelloid wall type mostly correlate with lower diversities during the transgressive phases. For regressive systems tracts, he identified low absolute abundances and high diversities, correlating with increased abundances of the oblique wall type and maximum abundances of the radial wall type.

The results of Zügel (1994) encourage the idea of a primarily sea-level-controlled distribution of calcareous dinoflagellates in the Lägerdorf chalks. The three intervals as distinguished by Hildebrand-Habel \& Willems (1997) would then represent a sequence of regression (koeneni Zone)-transgression (late MidConiacian to early Mid-Santonian interval)-regression (middle Mid-Santonian to Upper Santonian interval).

The possible pattern of regression-transgression-regression during the Middle Coniacian to Upper Santonian chalks of Lägerdorf is also reflected in the distribution of the newly described species (Fig. 1a): Pirumella fragilis and Ruegenia quinqueangulata only occur in the possibly transgressive interval, whereas Calcicarpinum macrogranulum is absent during this interval. The disappearance of $C$. macrogranulum during an interval characterized by a transgressive development has also been documented in an investigation of Upper Campanian to Lower Maastrichtian calcareous dinoflagellates of Lägerdorf (K. Bison, pers. comm., 2000): the species was present in the regressive Late Campanian interval (Haq et al., 1987), but absent in the transgressive latest Campanian and Early Maastrichtian succession.

The calcareous dinoflagellates of Lägerdorf-KronsmoorHemmoor that have been examined to date, exhibit distinct vertical assemblage changes. The distribution patterns show a good correlation with the sedimentological studies of Ehrmann (1986), who relates his results essentially to the sea-level fluctuations of Hancock \& Kauffman (1979). The Late Cretaceous was characterized by a long-term sea-level rise, which was only interrupted by short-term and slight regressions (Ehrmann, 1986). In the northwest European Late Cretaceous succession, a general transgressive trend can be observed for the Late Turonian to Middle Santonian interval, a nearly constant to slightly falling sea-level from Late Santonian to Early Campanian times, a rising sea-level during the Campanian and a regression during the Late Campanian, followed by a rising sea-level during the Early Maastrichtian interval (Hancock \& Kauffman, 1979). Certain parts of the Lägerdorf section, however, show sedimentological deviations which do not fit into the general concept of sea-level changes (Ehrmann, 1986). For instance, Ehrmann (1986) relates lowered carbonate contents and increased clay mineral and quartz contents during the
Coniacian interval to a regression. Such deviations from the general sedimentation processes may be due to local events (e.g. underground salt diapiric movements) or sedimentation in a marginal depression (G. Ernst, 1966; H. Ernst, 1978; Ehrmann, 1986). Although the changes in calcareous dinoflagellates of Lägerdorf-Kronsmoor-Hemmoor do not correspond perfectly to the sea-level curves of Hancock \& Kauffman (1979) and Haq et al. (1987), the pattern correlates well with the local sea-level changes, as suggested sedimentologically by Ehrmann (1986). The calcareous dinoflagellate assemblages obviously reflect local factors, rather than global sea-level changes.

\section{CONCLUSIONS}

The calcareous dinoflagellate assemblages of the Middle Coniacian to Upper Santonian chalks of Lägerdorf (northern Germany) contain three species which have not been previously formally described: Calcicarpinum macrogranulum n. sp., Pirumella fragilis $\mathrm{n}$. $\mathrm{sp}$. and Ruegenia quinqueangulata $\mathrm{n}$. $\mathrm{sp}$. The taxa show a vertical distribution that corresponds to calcareous dinoflagellate assemblage changes as discovered by HildebrandHabel \& Willems (1997). These assemblage changes allow a subdivision of the section into three parts which might result from local sea-level fluctuations: $P$. fragilis and $R$. quinqueangulata are restricted to the possibly transgressive upper Mid-Coniacian to Lower Santonian interval and $C$. macrogranulum occurs consistently only in the probably regressive lower Mid-Coniacian and Middle to Upper Santonian intervals.

\section{ACKNOWLEDGEMENTS}

The authors thank everyone at the Division Historical Geology and Palaeontology of Bremen University for their support and stimulating discussions. Peter Zügel is acknowledged for sharing his expertise in calcareous dinoflagellates and for kindly allowing use of his unpublished notes and photographs on calcareous dinoflagellate taxa from Lägerdorf. Particular thanks go to Joachim Schönfeld (Kiel) for providing the sample material. The authors are also grateful to two anonymous referees for their helpful comments.

\section{Manuscript received 3 July 2003 Manuscript accepted 6 February 2004}

\section{REFERENCES}

Bolli, H.M. 1974. Jurassic and Cretaceous Calcisphaerulidae from DSDP Leg 27, Eastern Indian Ocean. In: Veevers, J.J. \& Heirtzler, J.R. (Eds), Initial Reports of the Deep Sea Drilling Project, 27. US Government Printing Office, Washington, 843-907.

Bolli, H.M. 1980. Calcisphaerulidae and Calpionellidae from the Upper Jurassic and Lower Cretaceous of Deep Sea Drilling Project Hole 416A, Moroccan Basin. In: Lancelot, Y. \& Winterer, E.L. (Eds), Initial Reports of the Deep Sea Drilling Project, 50. US Government Printing Office, Washington, 525-543.

Bütschli, O. 1885. Protozoa. In: Bronn, H.G. (Ed.), Klassen und Ordnungen des Thier-Reichs, wissenschaftlich dargestellt in Wort und Bild, 1. Wintersche Verlagshandlung, Leipzig, 865-1088.

Deflandre, G. 1948. Les Calciodinellidés. Dinoflagellés fossiles à thèque calcaire. Le Botaniste, 34: 191-219.

Dias-Brito, D. 1985. Calcisphaerulidae e microfósseis associados da Formação Ponta do Mel - Bacia Potiguar, Brasil: considerações paleoecológicas e biochronoestratigráficas. Coletânea de Trabalhos Paleontológicos, Série Geologia, 27: 307-314. 
Ehrenberg, C.G. 1831. Animalia evertebrata. In: Hemprich, P.C. \& Ehrenberg, C.G. (Eds), Symbolae physicae. Pars zoologica. Abhandlungen der Akademie der Wissenschaften, Berlin.

Ehrmann, W.U. 1986. Zum Sedimenteintrag in das zentrale nordwesteuropäische Oberkreidemeer. Geologisches Jahrbuch (A), 97: $3-139$.

Ernst, G. 1966. Fauna, Ökologie und Stratigraphie der mittelsantonen Schreibkreide von Lägerdorf (SW-Holstein). Mitteilungen des Geologischen Staatsinstituts Hamburg, 35: 115-150.

Ernst, G. \& Schulz, M.-G. 1974. Stratigraphie und Fauna des Coniac und Santon im Schreibkreide-Richtprofil von Lägerdorf (Holstein) Mitteilungen des Geologisch-Paläontologischen Instituts der Universität Hamburg, 43: 5-60.

Ernst, H. 1978. Zu Bathymetrie und Sedimentstrukturen der Schreibkreide von Lägerdorf/Holstein (Coniac-Santon): Eine quantitative Analyse der Foraminiferen-Faunen. Mitteilungen des GeologischPaläontologischen Instituts der Universität Hamburg, 48: 53-78.

Esper, O., Zonneveld, K.A.F., Höll, C. et al. 2000. Reconstruction of palaeoceanographic conditions in the South Atlantic Ocean at the last two Terminations based on calcareous dinoflagellate cysts. International Journal of Earth Sciences, 88: 680-693.

Fensome, R.A., Taylor, F.J.R., Norris, G., Sarjeant, W.A.S., Wharton, D.I. \& Williams, G.L. 1993. A classification of living and fossil dinoflagellates. Micropaleontology Press Special Paper, 7. Sheridan Press, Hanover, Pennsylvania, 1-351.

Haeckel, E. 1894. Systematische Phylogenie. Entwurf eines natürlichen Systems der Organismen auf Grund ihrer Stammesgeschichte. Systematische Phylogenie der Protisten und Pflanzen, 1. Reimer, Berlin, $1-400$.

Hancock, J.M. \& Kauffman, E.G. 1979. The great transgressions of the Late Cretaceous. Journal of the Geological Society, London, 136 $175-186$.

Haq, B.U., Hardenbol, J. \& Vail, P.R. 1987. Chronology of fluctuating sea levels since the Triassic. Science, 235: 1156-1167.

Hildebrand-Habel, T. \& Streng, M. 2003. Calcareous dinoflagellate associations and Maastrichtian-Tertiary climatic change in a highlatitude core (ODP Hole 689B, Maud Rise, Weddell Sea). Palaeogeography, Palaeoclimatology, Palaeoecology, 197: 293-321.

Hildebrand-Habel, T. \& Willems, H. 1997. Calcareous dinoflagellate cysts from the middle Coniacian to upper Santonian chalk facies of Lägerdorf (N Germany). Courier Forschungsinstitut Senckenberg, 201: 177-199.

Hildebrand-Habel, T. \& Willems, H. 2000. Distribution of calcareous dinoflagellates from the Maastrichtian to early Miocene of DSDP Site 357 (Rio Grande Rise, western South Atlantic Ocean). International Journal of Earth Sciences, 88: 694-707.

Hildebrand-Habel, T., Willems, H. \& Versteegh, G.J.M. 1999. Variations in calcareous dinoflagellate associations from the Maastrichtian to middle Eocene of the western South Atlantic Ocean (São Paulo Plateau, DSDP Leg 39, Site 356). Review of Palaeobotany and Palynology, 106: 57-87.

Håkansson, E., Bromley, R.G. \& Perch-Nielsen, K. 1974. Maastrichtian chalk of Northwest Europe - a pelagic shelf sediment. In: Hsü, K.J. \& Jenkyns, H.C. (Eds), Pelagic sediments: on land and under the sea. Special Publication of the International Association of Sedimentologists, 1: 211-233.

Höll, C., Karwath, B., Rühlemann, C., Zonneveld, K.A.F. \& Willems, H. 1999. Palaeoenvironmental information gained from calcareous dinoflagellates: the late Quaternary eastern and western tropical Atlantic Ocean in comparison. Palaeogeography, Palaeoclimatology, Palaeoecology, 146: 147-164.

Janofske, D. 1996. Ultrastructure types in Recent 'calcispheres'. Bulletin de l'Institut océanographique, Monaco, 14(4): 295-303.

Keupp, H. 1981. Die kalkigen Dinoflagellaten-Zysten der borealen Unter-Kreide (Unter-Hauterivium bis Unter-Albium). Facies, 5 $1-190$.

Keupp, H. 1984. Revision der kalkigen Dinoflagellaten-Zysten G. Deflandres, 1948. Paläontologische Zeitschrift, 58(1/2): 9-31.

Keupp, H. 1992. Die Flora kalkiger Dinoflagellaten-Zysten im mittleren Apt (Gargas) der Kernbohrung Himstedt 3 bei Hoheneggelsen/ Niedersachsen. Berliner Geowissenschaftliche Abhandlungen (E), 3: $121-169$.
Keupp, H. 1995a. Vertical distribution of calcareous dinoflagellate cysts of the middle Aptian core section of the Hoheneggelsen KB 3 borehole, Lower Saxony, Germany. Neues Jahrbuch für Geologie und Paläontologie, Abhandlungen, 196(2): 221-233.

Keupp, H. 1995b. Die kalkigen Dinoflagellaten-Zysten aus dem OberAlb der Bohrung Kirchrode 1/91 (zentrales Niedersächsisches Becken, NW-Deutschland). Berliner Geowissenschaftliche Abhandlungen (E), 16: $155-199$.

Keupp, H. 2001. Palaeoenvironmental interpretation of late Albian calcareous dinoflagellate cysts from the Kirchrode I borehole (Lower Saxony Basin, NW Germany). Palaeogeography, Palaeoclimatology, Palaeoecology, 174: 251-267.

Keupp, H. \& Ilg, A. 1989. Die kalkigen Dinoflagellaten im OberCallovium und Oxfordium der Normandie/Frankreich. Berliner Geowissenschaftliche Abhandlungen (A), 106: 165-205.

Keupp, H. \& Mutterlose, J. 1984. Organismenverteilung in den D-Beds von Speeton (Unterkreide, England) unter besonderer Berücksichtigung der kalkigen Dinoflagellaten-Zysten. Facies, 10: 153-178.

Keupp, H., Monnet, B. \& Kohring, R. 1991. Morphotaxa bei kalkigen Dinoflagellaten-Zysten und ihre problematische Systematisierung. Berliner Geowissenschaftliche Abhandlungen (A), 134: 161-185.

Keupp, H., Kohring, R. \& Kowalski, F.-U. 1992. Neue Arten der Gattung Ruegenia Willems 1992 (kalkige Dinoflagellaten-Zysten) aus Kreide und Tertiär. Berliner Geowissenschaftliche Abhandlungen (E), 3: 191-209.

Kienel, U. 1994. Die Entwicklung der kalkigen Nannofossilien und der kalkigen Dinoflagellaten-Zysten an der Kreide/Tertiär-Grenze in Westbrandenburg im Vergleich mit Profilen in Nordjütland und Seeland (DK). Berliner Geowissenschaftliche Abhandlungen (E), 12: $1-87$.

Lentin, J.K. \& Williams, G.L. 1985. Fossil dinoflagellates: index to genera and species, 1985. Canadian Technical Report of Hydrography and Ocean Sciences, 60: 449pp.

Lentin, J.K. \& Williams, G.L. 1993. Fossil dinoflagellates: index to genera and species, 1993 Edition. AASP Contribution Series, 28. American Association of Stratigraphic Palynologists Foundation, Dallas, 856pp.

Pascher, A. 1914. Über Flagellaten und Algen. Berichte der deutschen botanischen Gesellschaft Berlin, 32: 136-160.

Reháková, D. 2000. Calcareous dinoflagellate and calpionellid bioevents versus sea-level fluctuations recorded in the West-Carpathian (Late Jurassic/Early Cretaceous) pelagic environments. Geologica Carpathica, 51(4): 229-243.

Schmid, F. 1982. Das erweiterte Unter-/Ober-Maastricht-Grenzprofil von Hemmoor, Niederelbe (NW-Deutschland). Geologisches Jahrbuch (A), 61: 7-12.

Schulz, M.-G. 1978. Zur Litho- und Biostratigraphie des ObercampanUntermaastricht von Lägerdorf und Kronsmoor (SW Holstein). Newsletters on Stratigraphy, 7(2): 73-89.

Schulz, M.-G., Grube, F. \& Menke, B. 1990. Exkursion N-2: Oberkreide von Lägerdorf / Perm und Altquartär von Lieth (Holstein). In: Willems, H., Wefer, G., Rinski, M. et al. (Eds), Beiträge zur Geologie und Paläontologie Norddeutschlands - Exkursionsführer. Berichte aus dem Fachbereich Geowissenschaften der Universität Bremen, 10: 173-202.

Schönfeld, J., Schulz, M.-G., McArthur, J.M. et al. 1996. New results on biostratigraphy, palaeomagnetism, geochemistry and correlation from the standard section for the Upper Cretaceous white chalk of northern Germany (Lägerdorf-Kronsmoor-Hemmoor). Mitteilungen des Geologisch-Paläontologischen Instituts der Universität Hamburg, 77: $545-575$.

Streng, M., Hildebrand-Habel, T. \& Willems, H. 2004. Long-term evolution of calcareous dinoflagellate associations since the Late Cretaceous: comparison of a high and a low latitude core from the Indian Ocean. Journal of Nannoplankton Research, 26(1).

Versteegh, G.J.M. 1993. New Pliocene and Pleistocene calcareous dinoflagellate cysts from southern Italy and Crete. Review of Palaeobotany and Palynology, 78: 353-380.

Vink, A. 2004. Calcareous dinoflagellate cysts in South and equatorial Atlantic surface sediments: diversity, distribution, ecology and potential for palaeoenvironmental reconstruction. Marine Micropaleontology, 50: 43-88. 
Vink, A., Willems, H. \& Zonneveld, K.A.F. 2000. Distributions of calcareous dinoflagellate cysts in surface sediments of the western equatorial Atlantic Ocean, and their potential use in palaeoceanography. Marine Micropaleontology, 38: 149-180.

Vink, A., Rühlemann, C., Zonneveld, K.A.F., Mulitza, S., Hüls, M. \& Willems, H. 2001. Shifts in the position of the North Equatorial Current and rapid productivity changes in the western Tropical Atlantic during the last glacial. Paleoceanography, 16(5): 479-490.

Vink, A., Brune, A., Höll, C., Zonneveld, K.A.F. \& Willems, H. 2002. On the response of calcareous dinoflagellates to oligotrophy and stratification of the upper water column in the equatorial Atlantic Ocean. Palaeogeography, Palaeoclimatology, Palaeoecology, 178 53-66.

Willems, H. 1985. Tetramerosphaera lacrimula, eine intern gefächerte Calcisphaere aus der Ober-Kreide. Senckenbergiana lethaea, 66(3/5): 177-201.

Willems, H. 1988. Kalkige Dinoflagellaten-Zysten aus der oberkretazischen Schreibkreide-Fazies N-Deutschlands (Coniac bis Maastricht). Senckenbergiana lethaea, 68(5/6): 433-477.

Willems, H. 1990. Tetratropis, eine neue Kalkdinoflagellaten-Gattung (Pithonelloideae) aus der Ober-Kreide von Lägerdorf (NDeutschland). Senckenbergiana lethaea, 70(1/3): 239-257.
Willems, H. 1992. Kalk-Dinoflagellaten aus dem Unter-Maastricht der Insel Rügen. Zeitschrift geologischer Wissenschaften, 20(1/2): $155-178$.

Willems, H. 1994. New calcareous dinoflagellates from the Upper Cretaceous white chalk of Northern Germany. Review of Palaeobotany and Palynology, 84: 57-72.

Williams, G.L., Lentin, J.K. \& Fensome, R.A. 1998. The Lentin and Williams index of fossil dinoflagellates, 1998 Edition. AASP Contribution Series, 34. American Association of Stratigraphic Palynologists Foundation, Dallas, 817pp.

Young, J.R., Bergen, J.A., Bown, P.R. et al. 1997. Guidelines for coccolith and calcareous nannofossil terminology. Palaeontology, 40(4): 875-912.

Zügel, P. 1994. Verbreitung kalkiger Dinoflagellaten-Zysten im Cenoman/Turon von Westfrankreich und Norddeutschland. Courier Forschungsinstitut Senckenberg, 176: 1-159.

Zügel, P. 1996. Distribution of calcareous dinoflagellate cysts in the Cenomanian/Turonian of western France. Mitteilungen des Geologisch-Paläontologischen Instituts der Universität Hamburg, 77: 191-201. 